\title{
Molecular Genetic Technique
}

National Cancer Institute

\section{Source}

National Cancer Institute. Molecular Genetic Technique. NCI Thesaurus. Code C19235.

The methods and tools used for DNA analysis and manipulation. 